\title{
BANKRUCTWO CZY STABILNOŚĆ RYNKOWA - ANALIZA WYBRANYCH POLSKICH MODELI DYSKRYMINACYJNYCH NA PRZYKŁADZIE SPÓŁKI ALMA MARKET SA
}

\author{
Kamil Janik \\ Politechnika Częstochowska \\ Wydział Zarządzania
}

\begin{abstract}
Streszczenie: W czasach nieustającej globalizacji i dążenia do rozwoju wiele podmiotów gospodarczych nie radzi sobie z zarządzaniem, co prowadzi do ich upadłości. Aby zminimalizować ryzyko upadłości, przedsiębiorstwa mają możliwość zastosowania modeli dyskryminacyjnych, potocznie nazywanych modelami wczesnego ostrzegania, które dadzą obraz przedsiębiorstwa pod kątem sytuacji ekonomiczno-finansowej. W artykule przeanalizowano przypadek spółki Alma Market SA, która ogłosiła swoją upadłość. Wykorzystano wybrane polskie modele dyskryminacyjne do wyznaczenia współczynników określających ryzyko upadłości spółki w danych okresach.
\end{abstract}

Słowa kluczowe: bankructwo, polskie modele dyskryminacyjne, upadłość

DOI: $10.17512 /$ znpcz.2018.1.20

\section{Wprowadzenie}

W obecnych zmiennych i turbulentnych czasach ważnym aspektem prowadzenia przedsiębiorstwa jest ocena jego zdolności pod kątem prowadzenia działalności gospodarczej oraz dostosowania się do zmienności otoczenia. Oznacza to zwiększenie skali zagrożeń, co w efekcie przekłada się na wzmożone ryzyko bankructwa. Odpowiednie rozpoznanie sytuacji ekonomicznej przedsiębiorstwa, a także opinia na temat zagrożeń bankructwem przyczyni się do dostarczenia informacji o sytuacji materialnej oraz umożliwi opracowanie prognozy przyszłej sytuacji fina sowo-majątkowej podmiotu gospodarczego. Ukazuje to możliwość rozwoju przedsiębiorstwa. W jednostce gospodarczej głównym czynnikiem upadku jest przede wszystkim brak odpowiedniej, wykwalifikowanej kadry kierowniczej, posiadającej zdolności menedżerskie. Kolejną przyczyną mającą realny wpływ na upadek podmiotu gospodarczego jest defraudacja finansowa polegająca na nieodpowiednim gospodarowaniu środkami pieniężnymi i majątkowymi oraz przekazywanie ich do wykorzystania prywatnego. Ostatnią, kluczową przyczyną prowadzącą do upadku przedsiębiorstwa jest nieumiejętne zarządzanie ryzykiem. Nierozpoznanie i brak zdefiniowania wyżej zaprezentowanych czynników z pewnością w dłuższym horyzoncie czasowym doprowadzi do niekorzystnych efektów w jednostce gospodarczej, a w ostateczności do upadłości. Upadłość w świetle przepisów prawnych jest finalnym etapem funkcjonowania przedsiębiorstwa. W literaturze przedmiotu można wyszukać wiele pozycji dotyczących bankructwa przedsię- 
biorstwa oraz jej czynników, a także restrukturyzacji, która jest stosowana podczas procesu upadłości i bankructwa jednostki gospodarczej. Zmiany prawne, a w szczególności efekt przeprowadzonych zmian polityki pieniężnej, doprowadziły do wytworzenia się pojęcia bankructwa. Pojęcia upadłości i bankructwa nie są tożsame, gdyż odnoszą się one i określają zupełnie inny stan w cyklu życia jednostki gospodarczej. Przyczyny upadłości przedsiębiorstwa można rozpatrywać $\mathrm{w}$ aspekcie wewnętrznym, jak i zewnętrznym. W przypadku pierwszego $\mathrm{z}$ aspektów odnosi się to do kierownictwa i zarządu mającego możliwość reagowania i działania, czyli ogólnie mówiąc, posiadającego możliwość ingerowania w czynności mające wpływ na kształtowanie się finansów przedsiębiorstwa. Otoczenie zewnętrzne i jego wpływ na upadłość firmy odgrywa znaczącą rolę ze szczególnym uwzględnieniem zmian stanu prawnego oraz panującej polityki finansowej. Czynniki te odnoszą się do funkcjonowania przedsiębiorstwa $\mathrm{w}$ danym otoczeniu i wpływu danego przedsiębiorstwa na otoczenie.

Głównym celem artykułu jest zaprezentowanie polskich modeli dyskryminacyjnych wykorzystywanych do badania kondycji finansowej przedsiębiorstwa, jak również do prognozowania upadłości. Ponadto zostanie określone, które modele wczesnego ostrzegania informowały o możliwości zaistnienia upadłości podmiotu gospodarczego, i będzie także opisana ich skuteczność. Badania zostaną oparte na przypadku spółki akcyjnej Alma Market. Zostaną wyznaczone wskaźniki dyskryminacyjne dla okresu 2013-2016. W artykule zastosowana będzie metoda statystyczna, mająca na celu poznanie zależności i prawidłowości zachodzących tendencji w przedsiębiorstwie. Ponadto użyta zostanie także metoda analizy przypadku, której zastosowanie umożliwi uzyskanie obrazu spółki i jej sytuacji finansowej, przez co powstanie możliwość wyciagnięcia wniosków empirycznych.

\section{Bankructwo jako główny czynnik upadku podmiotu gospodarczego}

W literaturze przedmiotu upadłość najczęściej jest definiowana jako długookresowa utrata przez podmiot gospodarczy zdolności spłacania swoich zobowiązań bądź jako deficyt majątkowy niewystarczający do uregulowania wygenerowanego długu. Pod terminem „bankructwo” należy rozumieć absolutną niewypłacalność przedsiębiorstwa i brak perspektyw na odzyskanie majątku (Rosiek, Zyguła 2009, s. 212-213). W miarę rosnących problemów w mikrootoczeniu (niefachowe kierowanie jednostką gospodarczą oraz brak umiejętnego zarządzania ryzykiem) dochodzi do stałego, narastającego zagrożenia bankructwem. Bankructwo jest definiowane jako niewypłacalność dłużnika wobec dochodzenia roszczeń przez wierzycieli. To z kolei prowadzi do odzyskania środków ze wszystkich posiadanych składników majątku. W myśl prawa upadłościowego jest to postępowanie czynione względem dłużnika, który stał się niewypłacalny względem wierzycieli. Postępowanie upadłościowe zostaje rozpoczęte w momencie ogłoszenia przez sąd upadłości podmiotu gospodarczego (Ustawa z dnia 28 lutego 2003 r. ...). Natomiast w myśl art. 11 Ustawy z dnia 11 maja 2015 r. - Prawo restrukturyzacyjne, jeżeli jednocześnie zostaną złożone wnioski dotyczące upadłości oraz restruktury- 
zacji, to w pierwszej kolejności rozpatrywany jest wniosek restrukturyzacyjny (Ustawa z dnia 15 maja 2015 r. ...).

Różne przedsiębiorstwa mają różny stopień podatności na bankructwo. Podatność ta jest zróżnicowana i uzależniona od wielkości firmy, pozycji na rynku, jak również od sposobu i strategii kierowania. Ponadto znaczącą rolę w procesie upadłości przedsiębiorstwa odgrywa makrootoczenie. Dodatkowo istotny wpływ na kształtowanie się stabilności rynkowej podmiotu gospodarczego ma konkurencja, która odgrywa mocną rolę $\mathrm{w}$ ilości pozyskiwanych klientów, co przekłada się w konsekwencji na poziom uzyskiwanych dochodów. Celem każdej firmy powinno być stałe powiększanie swojego majątku, a nie wyłącznie przetrwanie i egzystencja rynkowa. Bankructwo, a co za tym idzie upadłość, traktowane jest jako naturalna selekcja na rynku (Mączyńska, Morawska 2015, s. 73-74).

W celu oceny stopnia upadłości podmiotu gospodarczego stosowana jest analiza dyskryminacyjna, polegająca na przeglądzie danych prezentowanych przez przedsiębiorstwa $\mathrm{w}$ celu dokonania porównania pomiędzy nimi. Prekursorem i ojcem analizy dyskryminacyjnej jest Ronald Fisher, który opracował tę teorię w 1936 roku (Pociecha (red.) 2014, s. 17). Metoda pozwala na kategoryzację obiektów przy zastosowaniu wielu danych opracowywanych równocześnie. Podczas badania zagrożenia bankructwem wykorzystywany jest model liniowy funkcji dyskryminacyjnej. Funkcja wyrażana jest w postaci (Kasjaniuk 2006, s. 95):

$$
Z=b_{0}+b_{1} X_{1}+b_{2} X_{2}+\ldots+b_{k} X_{k}
$$

gdzie:

Z - zmienna objaśniana, która ukazuje sytuację ekonomiczną podmiotu gospodarczego;

$b_{0}$ - wartość stała;

$b_{i}$ - współczynnik dyskryminacyjny;

$X_{i}$ - zmienna objaśniająca.

Wyznaczenie wartości funkcji dyskryminacyjnej prowadzi do zestawienia i porównania $\mathrm{z}$ określonymi wartościami granicznymi, co umożliwia właściwe zaklasyfikowanie badanego obiektu do grupy obiektów zagrożonych bankructwem i upadłością lub do grupy podmiotów gospodarczych o stabilnej kondycji finansowej.

W literaturze przedmiotu modele dyskryminacyjne charakteryzowane są jako główne składowe oceny sytuacji ekonomicznej podmiotu gospodarczego. Oceny wynikające $\mathrm{z}$ analizy ekonomicznej dostarczają informacji dotyczących sytuacji finansowej oraz czynników, które ukazują możliwość upadłości. Stosowanie i wykorzystywanie modeli dyskryminacyjnych ma zarówno swoje zalety, jak i wady. Do podstawowych zalet można zaliczyć fakt, że istnieje możliwość pomiaru wszystkich czynników poprzez ich dobór w sposób statystyczny. Kolejnym ważnym aspektem przemawiającym za wykorzystywaniem modeli oceny zagrożenia jest to, że charakteryzują się one wyselekcjonowaną grupą wskaźników, które w efekcie zmierzają do wytworzenia jednego, ogólnego wskaźnika. Ponadto za zastosowaniem modeli upadłości przemawia argument, iż są proste do zastosowania w podmiocie gospodarczym. Do kolejnej zalety modeli dyskryminacyjnych można zaliczyć fakt, że posiadają wysoką efektywność sprawdzalności (Tłuczak 
2013, s. 423-425). Jednocześnie takie modele dysponują również wadami. Największą wadą jest brak umiędzynarodowienia, polegający na tym, że polskie modele dyskryminacyjne mogą być zastosowane wyłącznie na terenie Rzeczypospolitej Polskiej. Poza tym terytorium będą one niewiarygodne i niemiarodajne. Kolejną wadą płynącą z wykorzystania tych modeli jest fakt, że zostają oparte na danych statystycznych, finansowych, mających swoje umiejscowienie w przeszłości, czyli wykorzystywane są tzw. dane historyczne. Warto również zauważyć, iż przedsiębiorstwa nie mogą opierać się tylko i wyłącznie na jednym mierniku oceny upadłości, gdyż może on nie odzwierciedlić optymalnie i racjonalnie sytuacji ekonomiczno-finansowej podmiotu gospodarczego (Bombiak 2010, s. 147-148).

Stosowanie narzędzi związanych z modelami dyskryminacyjnymi upowszechniło się również w Polsce. W artykule zostaną zaprezentowane i zbadane wybrane polskie modele oceny upadłości i zostanie oceniona efektywność ich sprawdzalności na przykładzie spółce akcyjnej Alma Market.

\section{Charakterystyka polskich modeli dyskryminacyjnych}

Większa część polskich modeli dyskryminacyjnych została opracowana przy wykorzystaniu liniowej analizy dyskryminacyjnej. W artykule zostanie omówionych i zaprezentowanych sześć polskich modeli dyskryminacyjnych.

Pierwszym polskim modelem, który zostanie omówiony, będzie model opracowany przez Jerzego Gajdka i Daniela Stosa. Model został opracowany na bazie 40 przedsiębiorstw, z których połowa posiadała znamiona upadłościowe, natomiast druga połowa to podmioty, które znamionowała stabilna kondycja finansowa. Próbę przedsiębiorstw o dobrej kondycji finansowej stanowiły podmioty gospodarcze notowane na giełdzie. Ponadto przedsiębiorstwa zostały wyselekcjonowane z branży przemysłowej, budowlanej oraz handlowej. Dane finansowe zostały zaczerpnięte z dwóch kolejnych lat, czyli z roku 1994 i 1995. Owymi danymi posłużono się do określenia wskaźników niezbędnych do zastosowania modelu. Sprawozdania finansowe pochodziły z roku poprzedzającego upadłość podmiotu gospodarczego (Prusak 2005, s. 130-135).

Model został opisany w poniższy sposób, przy jednoczesnym założeniu, że wartość graniczna $Z$ będzie równa 0,44 .

$Z=0,20098985 X_{1}+0,0013027 X_{2}+0,7609754 X_{3}+0,9659628 X_{4}-0,341096 X_{5}$

gdzie:

$X_{1}$ - przychody netto ze sprzedaży dzielone przez średnią wartość aktywów;

$X_{2}$ - średnie zobowiązania krótkoterminowe w okresie 365 dni, dzielone przez koszty wytworzenia wyrobów sprzedanych;

$X_{3}$ - wynik netto dzielony przez średnią wartość aktywów;

$X_{4}$ - wynik brutto dzielony przez przychody ze sprzedaży;

$X_{5}$ - zobowiązania ogółem dzielone przez aktywa razem. 
Kolejnym scharakteryzowanym modelem będzie model autorstwa Doroty Hadasik, który został opracowany na podstawie podmiotów gospodarczych posiadających różną formę prawną, wyselekcjonowanych w latach 1991-1997, które złożyły wniosek upadłościowy. Badanie i opracowywanie modelu zostało ograniczone terytorialnie do trzech miast, czyli Poznania, Piły oraz Leszna (Hadasik 1998, s. 133-170). Badane przedsiębiorstwa były zróżnicowane pod kątem wielkości, a także branży. Natomiast podmioty gospodarcze niezagrożone upadłością i bankructwem zostały dobrane pod kątem formy własnościowej oraz wielkości przedsiębiorstwa. Dobór ten był podporządkowany przedsiębiorstwom upadłym. Model został oparty na 39 przedsiębiorstwach posiadających stabilną kondycję finansową oraz na 22 przedsiębiorstwach, które ogłosiły upadłość. Jednocześnie, dokonując doboru próby, uznano, iż podmioty gospodarcze tworzące pojedyncze pary nie muszą być z jednakowej branży. Punkt graniczny modelu został przyjęty w punkcie 0. Model został określony następującym wzorem (Hadasik 1998, s. 152-155):

$$
Z=-2,50761 X_{1}+0,00141147 X_{2}-0,00925162 X_{3}+0,0233545 X_{4}+2,6083
$$

gdzie:

$X_{I}$ - zobowiązania ogółem dzielone przez aktywa ogółem;

$X_{2}$ - należności w okresie 365 dni dzielone przez przychody ze sprzedaży;

$X_{3}$ - zapasy mnożone przez 365 , dzielone przez przychody ze sprzedaży;

$X_{4}-$ zysk netto dzielony przez zapasy.

Trzecim polskim modelem dyskryminacyjnym jest model autorstwa Dariusza Wierzby. Autor w opracowaniu modelu wykorzystał próbę składającą się z 24 podmiotów gospodarczych zagrożonych bankructwem. Wykorzystano tę samą liczbę przedsiębiorstw posiadających stabilną kondycję finansową. Podmioty upadłe zostały wyselekcjonowane w okresie: począwszy od stycznia 1995 roku, a skończywszy na 1998 roku. W tym czasie autorowi udało się dotrzeć wyłącznie do 13 przedsiębiorstw, które publikowały swoje sprawozdania finansowe. Do skonstruowania modelu potrzeba większej ilości podmiotów gospodarczych, dlatego zdecydowano się na poszerzenie obszaru przedsiębiorstw ujmowanych jako zagrożone ryzykiem bankructwa. W ostatecznym rozrachunku autorowi modelu udało się zgromadzić sprawozdania finansowe 24 przedsiębiorstw upadłych bądź zagrożonych upadłością. Posiadając tę grupę 24 przedsiębiorstw, dobrano podmioty gospodarcze o stabilnej kondycji finansowej. Model został określony wzorem (Antonowicz 2007, s. 70-71):

$$
Z=3,26 X_{1}+2,16 X_{2}+0,3 X_{3}+0,69 X_{4}
$$

gdzie:

$X_{l}$ - wyznacza się jako iloraz różnicy zysków z działalności operacyjnej, minus amortyzacja, dzielone przez łączną sumę aktywów;

$X_{2}$ - iloraz zysków z działalności operacyjnej, minus amortyzacja, dzielone przez sprzedaż produktów;

$X_{3}$ - iloraz aktywów obrotowych do zobowiązań całkowitych;

$X_{4}$ - iloraz kapitału obrotowego do aktywów ogółem. 
Kolejnym polskim modelem dyskryminacyjnym jest model opracowany przez Artura Hołdę w latach 1993-1996 na podstawie sprawozdań finansowych polskich przedsiębiorstw. Autor określił model w następującej postaci (Rogowska, Lipski 2014, s. 22):

$$
Z=0,605+0,681 X_{1}-0,0196 X_{2}+0,00969 X_{3}+0,000672 X_{4}+0,157 X_{5}
$$

gdzie:

$X_{I}$ - wyznaczane jest jako różnica pomiędzy aktywami obrotowymi a krótkoterminowymi zobowiązaniami;

$X_{2}$ - określane jest jako różnica pomiędzy zobowiązaniami ogółem a zobowiązaniami krótkoterminowymi;

$X_{3}$ - wyliczane jest na podstawie ilorazu wyniku finansowego netto przez przeciętny stan aktywów ogółem;

$X_{4}$ - obliczane jest jako iloraz przeciętnego stanu zobowiązań krótkoterminowych przez różnicę pomiędzy kosztami działalności operacyjnej a pozostałymi kosztami operacyjnymi;

$X_{5}$ - wyznaczane jest pod postacią ilorazu przychodów ogółem przez przeciętny stan aktywów ogółem.

Piątym omawianym modelem jest model autorstwa Elżbiety Mączyńskiej i Macieja Zawadzkiego. Opierał się na badaniu 80 podmiotów gospodarczych ukierunkowanych na branżę produkcyjną, usługową oraz handlową. W danym modelu punkt graniczny został wyznaczony w punkcie 0 . Model został opisany następującym wzorem (Rupiewicz 2015, s.120-121):

$$
Z=9,498 X_{1}+3,566 X_{2}+2,903 X_{3}+0,452 X_{4}-1,498
$$

gdzie:

$X_{1}$ - iloraz pomiędzy wynikiem operacyjnym a aktywami ogółem;

$X_{2}$ - iloraz pomiędzy kapitałem własnym a aktywami ogółem;

$X_{3}$ - iloraz pomiędzy sumą wyniku netta i amortyzacją a zobowiązaniami ogółem;

$X_{4}$ - iloraz aktywów obrotowych przez zobowiązania krótkoterminowe.

Ostatnim, szóstym omawianym modelem dyskryminacyjnym jest model „poznański”. Został on oparty na badaniu 100 podmiotów gospodarczych z lat 1999-2002. Przedsiębiorstwa podzielono na dwie grupy. Do pierwszej zostały przyporządkowane spółki charakteryzujące się stabilną kondycją finansową. Natomiast do drugiej grupy zostały przydzielone podmioty gospodarcze o znamionach upadłości. W modelu ,poznańskim” punkt graniczny oszacowano jako 0. Model został określony następującym wzorem (Antonowicz 2007, s. 56-57):

$$
Z=3,562 X_{1}+1,588 X_{2}-4,288 X_{3}+6,719 X_{4}-2,368
$$

$X_{1}=\frac{\text { wynik finansowy netto }}{\text { majątek całkowity }}$

$X_{2}=\frac{\text { aktywa obrotowe-zapasy }}{\text { zobowiąania krótkoterminowe }}$

$X_{3}=\frac{\text { kapitał stały }}{\text { majątek całkowity }}$

$X_{4}=\frac{\text { wynik finansowy ze sprzedaży }}{\text { przychody netto ze sprzedaży }}$ 
Wyżej zaprezentowane modele dyskryminacyjne są przydatne do oceny kondycji finansowej podmiotu gospodarczego, jak i do podjęcia decyzji odnoszących się do zarządzania przedsiębiorstwem. Analizując uzyskane wartości zastosowanych wskaźników, można uzyskać obraz przedsiębiorstwa oraz podjąć niezbędne kroki w celu poprawy zaistniałej sytuacji. Omawiane modele wczesnego ostrzegania są niezmiernie pomocne w procesie zarządczym jednostką gospodarczą. Przedsiębiorstwa wykorzystujące i stosujące modele dyskryminacyjne zyskują możliwość szybszego i efektywniejszego reagowania poprzez wydanie odpowiednich postanowień i rozporządzeń i ich wdrażanie oraz zarządzanie kapitałem, jak i także innymi składowymi tworzącymi całościowy obraz podmiotu gospodarczego. Dlatego należy zauważyć, iż zastosowanie modeli wczesnego ostrzegania jest ściśle powiązane z procesem decyzyjnym oraz z zarządzaniem przedsiębiorstwem. Dopiero wszystkie z tych czynników dają możliwość skutecznego oraz efektywnego zarządzania firmą. Modele te można zaimplementować i zastosować w przedsiębiorstwie do podejmowania decyzji strategicznych, operacyjnych oraz bieżących. Jest to niezbędne do podjęcia kluczowych postanowień inwestycyjnych oraz przy emisji papierów wartościowych, a w szczególności papierów dłużnych. Dodatkowo modele wczesnego ostrzegania mogą być niezbędne podczas zawierania umów partnerskich oraz dokonywania fuzji podmiotów gospodarczych, gdyż brak oceny ryzyka upadłości będzie się wiązał ze zwiększoną ilością poniesionych kosztów. W sferze operacyjnej realizowane decyzje odnoszą się przede wszystkim do doboru odpowiednich dostawców oraz łańcucha dystrybucji, gdzie niezbędne jest zbadanie sytuacji ekonomicznej, która jest konieczna do odpowiedniego kierowania przedsiębiorstwem. Dodatkowo do podejmowania decyzji operacyjnych przy zastosowaniu modeli wczesnego ostrzegania należy zaliczyć wybór głównego ośrodka bankowego oraz transakcje papierami wartościowymi. Natomiast decyzje bieżące odnoszą się do doboru partnerów handlowych, czyli do wyselekcjonowania przedsiębiorstw, które będą w stanie zagwarantować świadczenia usług na jak najwyższym poziomie, a jednocześnie nie będą zagrożone upadłością. Dla wszystkich wyżej wymienionych obszarów decyzyjnych ważnym aspektem jest przeprowadzenie analizy sytuacji majątkowo-finansowej przy zastosowaniu prezentowanych modeli dyskryminacyjnych. Dlatego należy zwrócić szczególną uwagę na fakt, iż są one nieodłączną częścią zarządzania podmiotem gospodarczym.

W dalszej części artykułu zostaną dokonane badania mające na celu wykazać, iż nie wszystkie zastosowane modele dyskryminacyjne określają możliwość zaistnienia ryzyka związanego z upadłością podmiotu gospodarczego w tym samym okresie.

\section{Zastosowanie polskich modeli dyskryminacyjnych do oceny ryzyka upadku spółki Alma Market SA}

Do wykonania badania i pomiaru ryzyka upadłości oraz bankructwa podmiotu gospodarczego zostanie zastosowanych sześć polskich modeli dyskryminacyjnych, czyli modele autorstwa Jerzego Gajdki i Daniela Stosa, Doroty Hadasik, Dariusza Wierzby, Artura Hołdy, Elżbiety Mączyńskiej i Macieja Zawadzkiego oraz model „poznański”. Za okres badany zostały przyjęte 4 lata. 
Na początek zostaną wyznaczone współczynniki dyskryminacyjne modelu Jerzego Gajdki i Daniela Stosa w poszczególnych latach.

Tabela 1. Wyniki analizy zagrożenia według modelu J. Gajdki i D. Stosa

\begin{tabular}{|c|c|c|c|c|}
\hline Rok & $\mathbf{2 0 1 3}$ & $\mathbf{2 0 1 4}$ & $\mathbf{2 0 1 5}$ & $\mathbf{2 0 1 6}$ \\
\hline$X_{1}$ & 1,73 & 1,71 & 1,77 & 2,20 \\
\hline$X_{2}$ & $-119,50$ & $-126,46$ & $-148,06$ & $-285,03$ \\
\hline$X_{3}$ & 0,012 & $-0,02$ & $-0,18$ & $-0,72$ \\
\hline$X_{4}$ & 0,006 & $-0,01$ & $-0,11$ & $-0,31$ \\
\hline$X_{5}$ & 0,60 & 0,62 & 0,79 & 1,31 \\
\hline$Z$ & $-0,2787$ & $-0,049$ & $-0,3499$ & $-1,1598$ \\
\hline
\end{tabular}

Źródło: Opracowanie własne na podstawie (http://almmarket.pl/...)

W modelu Jerzego Gajdki i Daniela Stosa już od pierwszego badanego okresu, czyli 2013 roku, było ukazane możliwe zagrożenie bankructwem i upadkiem, gdyż został przekroczony oszacowany punkt graniczny. Przekroczenie punktu granicznego świadczy o złej kondycji ekonomiczno-finansowej. W następnym roku, pomimo iż nastąpiło zmniejszenie się wskaźnika, to jednak stale znajdował się on w sferze, która sugeruje i świadczy o możliwości upadku i bankructwa podmiotu gospodarczego. W następnych dwóch latach nastąpiło stałe i dynamiczne zwiększenie się wskaźnika dyskryminacyjnego. Tak szybkie zwiększenie się tego wskaźnika sugeruje, iż nastąpiło nagłe pogorszenie kondycji finansowej i ekonomicznej badanej spółki. Można powiedzieć, iż model Jerzego Gajdki i Daniela Stosa w każdym $\mathrm{z}$ badanym okresów sugerował i ukazywał ryzyko związane z zaistnieniem upadłości spółki. Dodatkowo można zaobserwować zmiany zachodzące w wartościach poszczególnych współczynników. Pierwszy współczynnik nie ma jednorodnie określonej tendencji. Pomiędzy dwoma pierwszymi latami dochodzi do minimalnego zmniejszenia się wartości tego współczynnika, natomiast w następnych dwóch latach następuje znaczący jego wzrost. Jeżeli chodzi o współczynniki od drugiego do czwartego, to można zaobserwować stałą tendencję malejącą w badanym okresie czasowym. Natomiast ostatni, piąty wskaźnik ukazuje stałą tendencję wzrostową.

Drugi zastosowany model autorstwa Doroty Hadasik prezentował następujące wskaźniki w poszczególnych latach.

Tabela 2. Wyniki analizy zagrożenia według modelu Doroty Hadasik

\begin{tabular}{|c|c|c|c|c|}
\hline Rok & $\mathbf{2 0 1 3}$ & $\mathbf{2 0 1 4}$ & $\mathbf{2 0 1 5}$ & $\mathbf{2 0 1 6}$ \\
\hline$X_{1}$ & 0,60 & 0,62 & 0,79 & 1,31 \\
\hline$X_{2}$ & 15,70 & 18,68 & 16,29 & 12,09 \\
\hline$X_{3}$ & 32,11 & 34,48 & 32,96 & 7,02 \\
\hline$X_{4}$ & 0,08 & $-0,10$ & $-1,14$ & $-17,42$ \\
\hline$Z$ & 0,8307 & 0,7615 & 0,3188 & $-1,1313$ \\
\hline
\end{tabular}

Źródło: Opracowanie własne na podstawie (http://almmarket.pl/...) 
W modelu dyskryminacyjnym autorstwa Doroty Hadasik punkt graniczny został oszacowany w punkcie 0 . W pierwszych trzech latach wyliczony współczynnik dyskryminacyjny przyjął wartość dodatnią, więc nie powinno wystąpić zagrożenie bankructwem i upadłością podmiotu gospodarczego. Jednakże warto zwrócić uwagę na fakt, iż w trzech pierwszych badanych latach dochodziło do stopniowego zmniejszania się wskaźnika dyskryminacyjnego i zmierzania do punktu granicznego. Mogło to być alarmujące zjawisko dla kierownictwa podmiotu gospodarczego. Dzięki zaobserwowaniu tego zjawiska miałoby ono możliwość reagowania i zahamowania wpływu negatywnych czynników. W 2016 roku zaobserwowano znaczące i gwałtowne zmniejszenie się wskaźnika dyskryminacyjnego, co świadczy i sugeruje, iż spółka jest silnie narażona na bankructwo, a co za tym idzie - na upadek podmiotu gospodarczego. Wpływ na tak duże zmniejszenie się wskaźnika miała redukcja posiadanych aktywów. Ponadto ważnym czynnikiem jest odnotowanie znaczącej straty netto. Te dwa główne czynniki miały kluczowy wpływ na kształtowanie się wskaźnika w tym modelu. Dodatkowo warto zwrócić uwagę na kształtowanie się poszczególnych współczynników. Pierwszy współczynnik $X_{I}$ ma stałą tendencję rosnącą $\mathrm{w}$ każdym $\mathrm{z}$ poszczególnych badanych okresów. We współczynnikach $X_{2}$ i $X_{3}$ można zauważyć prawidłowość, iż ich wartość wzrasta w tych samych okresach oraz maleje również w tych samych latach. Natomiast współczynnik $X_{4}$ posiada stałą malejącą tendencję, która najbardziej jest zauważalna pomiędzy 2015 a 2016 rokiem.

Trzecim modelem dyskryminacyjnym, za pomocą którego została przebadana spółka, jest model autorstwa Dariusza Wierzby.

Tabela 3. Wyniki analizy zagrożenia według modelu Dariusza Wierzby

\begin{tabular}{|c|c|c|c|c|}
\hline Rok & $\mathbf{2 0 1 3}$ & $\mathbf{2 0 1 4}$ & $\mathbf{2 0 1 5}$ & $\mathbf{2 0 1 6}$ \\
\hline Wskaźnik & 0,07 & 0,04 & $-0,15$ & $-0,31$ \\
\hline$X_{1}$ & 0,04 & 0,02 & $-0,08$ & $-0,14$ \\
\hline$X_{2}$ & 0,39 & 0,42 & 0,34 & 0,04 \\
\hline$X_{3}$ & $-0,16$ & $-0,32$ & $-0,32$ & $-1,21$ \\
\hline$X_{4}$ & 0,3212 & 0,0788 & $-0,7806$ & $-2,1359$ \\
\hline$Z$ &
\end{tabular}

Źródło: Opracowanie własne na podstawie (http://almmarket.pl/...)

W 2013 i 2014 roku wskaźniki dyskryminacyjne sytuowały się powyżej punktu granicznego, który w tym modelu został określony w punkcie 0. Jednakże warto zwrócić uwagę, iż pomiędzy 2013 a 2014 rokiem nastąpiło zmniejszenie wartości wskaźnika, co spowodowane było zwiększoną ilością wartości aktywów, a także wzmożoną sprzedażą i uzyskanymi przychodami ze sprzedaży. W 2014 roku wartość wskaźnika dyskryminacyjnego została wyznaczona na poziomie 0,0788 , czyli bardzo zbliżonym do oszacowanego punktu granicznego. Sugerowało to kierownictwu podmiotu gospodarczego niesprzyjające symptomy mogące przyczynić się do wystąpienia problemów finansowych. W następnych dwóch latach doszło do przekroczenia punktu granicznego, przez co istniało duże ryzyko zaistnienia kryzy- 
su finansowego i ekonomicznego w podmiocie gospodarczym, co w konsekwencji mogło prowadzić do bankructwa i upadku spółki. W tych dwóch latach największy wpływ na ujemny wskaźnik miały aktywa będące w posiadaniu spółki, które pomiędzy 2015 a 2016 rokiem zmniejszyły się prawie dwukrotnie. Ponadto duży wpływ na kształtowanie się wskaźnika miały uzyskiwane netto przychody ze sprzedaży. W 2016 roku w porównaniu z rokiem ubiegłym wielkość przychodów uzyskanych z tytułu sprzedaży była mniejsza o ponad 370 tys. zł. Dlatego znaczące zmiany tych dwóch czynników doprowadziły do ukazania się oznak wzmożonego ryzyka bankructwem oraz upadkiem przedsiębiorstwa. W tym modelu wartości współczynników $X_{1}$ i $X_{2}$ mają stałą tendencję malejącą, natomiast trzeci współczynnik pomiędzy 2013 a 2014 rokiem odnotowuje wzrost swojej wartości. Z kolei w dwóch kolejnych latach jego wartość znacząco się zmniejsza. Wartości czwartego współczynnika w modelu Dariusza Wierzby maleją, z wyłączeniem 2014 i 2015 roku. Pomiędzy tymi dwoma latami można zaobserwować stałą wartość wskaźnika.

Czwartym zastosowanym modelem dyskryminacyjnym w badaniu spółki Alma Market jest model Artura Hołdy. Punkt graniczny został ustalony w punkcie 0.

Tabela 4. Wyniki analizy zagrożenia według modelu Artura Hołdy

\begin{tabular}{|c|c|c|c|c|}
\hline Rok & $\mathbf{2 0 1 3}$ & $\mathbf{2 0 1 4}$ & $\mathbf{2 0 1 5}$ & $\mathbf{2 0 1 6}$ \\
\hline$X_{1}$ & 0,59 & 0,57 & 0,46 & 0,10 \\
\hline$X_{2}$ & 0,60 & 0,62 & 0,79 & 1,31 \\
\hline$X_{3}$ & 0,01 & $-0,02$ & $-0,18$ & $-0,74$ \\
\hline$X_{4}$ & $-0,82$ & $-0,24$ & $-1,31$ & $-2,12$ \\
\hline$X_{5}$ & 1,73 & 1,70 & 1,62 & 1,28 \\
\hline$Z$ & 1,2607 & 1,2471 & 1,1545 & 0,8401 \\
\hline
\end{tabular}

Źródło: Opracowanie własne na podstawie (http://almmarket.pl/...)

W przypadku modelu autorstwa Artura Hołdy wszystkie wartości poniżej punktu granicznego oznaczają zagrożenie wystąpienia bankructwa i upadłości podmiotu gospodarczego. W czterech badanych latach nie zaobserwowano ryzyka upadłości. Jednakże z roku na rok można zauważyć zmierzanie wskaźnika dyskryminacyjnego modelu w kierunku punktu granicznego, dlatego można jednoznacznie stwierdzić, iż dany wskaźnik miał tendencję malejącą, co może sugerować i świadczyć o stale pogarszającej się sytuacji ekonomiczno-finansowej spółki. Wartości współczynników $X_{1}, X_{3}$ i $X_{5}$ mają tendencję malejącą, natomiast wartości dwóch pozostałych wskaźników stale rosną w badanym okresie czasowym.

Piątą zastosowaną funkcją jest model autorstwa Elżbiety Mączyńskiej i Macieja Zawadzkiego. Punkt graniczny został ustalony w wartości 0. 
Tabela 5. Wyniki analizy zagrożenia według modelu Elżbiety Mączyńskiej i Macieja Zawadzkiego

\begin{tabular}{|c|c|c|c|c|}
\hline Rok & $\mathbf{2 0 1 3}$ & $\mathbf{2 0 1 4}$ & $\mathbf{2 0 1 5}$ & $\mathbf{2 0 1 6}$ \\
\hline$X_{1}$ & 0,01 & $-0,004$ & $-0,21$ & $-0,40$ \\
\hline$X_{2}$ & 0,40 & 0,38 & 0,21 & $-0,31$ \\
\hline$X_{3}$ & $-0,06$ & $-0,10$ & $-0,31$ & $-0,62$ \\
\hline$X_{4}$ & 0,59 & 0,56 & 0,46 & 0,27 \\
\hline$Z$ & 0,1159 & $-0,2181$ & $-3,4356$ & $-8,1574$ \\
\hline
\end{tabular}

Źródło: Opracowanie własne na podstawie (http://almmarket.pl/...)

W 2013 roku, mimo iż wskaźnik dyskryminacyjny znajdował się powyżej punktu granicznego, to jednak nie jest to duża nadwyżka, co sugeruje, iż możliwe jest wystąpienie zjawiska upadłości. Świadczy to o niestabilnej kondycji ekonomiczno-finansowej podmiotu gospodarczego. W każdym następnym badanym roku wartość wskaźnika została określana poniżej punktu granicznego. Wskaźnik dyskryminacyjny z każdym kolejnym rokiem miał tendencję malejącą. Począwszy od 2014 roku, można zaobserwować zwiększone ryzyko bankructwem i upadłością. Z roku na rok poziom tego ryzyka zwiększał się i świadczył o bardzo niestabilnej i złej sytuacji majątkowo-finansowej podmiotu gospodarczego. Wpływ na stałą tendencję malejącą wskaźnika dyskryminacyjnego miały zmiany zachodzące w uzyskiwanych zyskach netto z działalności oraz wielkość aktywów będących w posiadaniu spółki. Znaczące zmiany w tych dwóch obszarach okazały się kluczowe dla kształtowania się wartości wskaźnika modelu w poszczególnych latach i informowały o możliwym zagrożeniu bankructwem dla podmiotu gospodarczego, a w efekcie upadłością. Warto zaobserwować, iż w każdym z badanych okresów wszystkie współczynniki zmniejszały swoją wartość.

Ostatnim, szóstym zastosowanym modelem do zbadania spółki Alma Market SA jest model „poznański”. Punkt graniczny tego modelu został określony w punkcie 0 .

Tabela 6. Wyniki analizy zagrożenia według modelu „poznańskiego”

\begin{tabular}{|c|c|c|c|c|}
\hline Rok & $\mathbf{2 0 1 3}$ & $\mathbf{2 0 1 4}$ & $\mathbf{2 0 1 5}$ & $\mathbf{2 0 1 6}$ \\
\hline$X_{1}$ & 0,01 & $-0,02$ & $-0,20$ & $-0,72$ \\
\hline$X_{2}$ & 0,22 & 0,22 & 0,17 & 0,06 \\
\hline$X_{3}$ & 0,40 & 0,38 & 0,21 & $-0,31$ \\
\hline$X_{4}$ & 0,28 & 0,28 & 0,27 & 0,27 \\
\hline$Z$ & $-1,8169$ & $-1,8379$ & $-1,8968$ & $-1,6939$ \\
\hline
\end{tabular}

Źródło: Opracowanie własne na podstawie (http://almmarket.pl/...)

W modelu ,poznańskim” z dokonanych pomiarów wynika, iż w każdym badanym roku występowało zagrożenie upadłością. Jednakże w trzech pierwszych latach współczynnik miał tendencję rosnącą i wiązało się to ze stale malejącym pozyskiwaniem zysku netto, a także stale rosnącym zobowiązaniem. W 2016 roku 
odnotowano zmniejszenie się wartości wskaźnika dyskryminacyjnego. W każdym z badanych okresów model informował i alarmował o możliwości bankructwa i upadłości spółki. Zwracając uwagę na wartości współczynników, można zauważyć, że wartości liczbowe we współczynniku $X_{4}$ znajdują się na tym samym poziomie, co świadczy o tym, iż pomiędzy 2013 a 2014 oraz 2015 i 2016 rokiem tendencja wskaźnika była stała. Podobną tendencję można zaobserwować w wyliczeniach współczynnika $X_{2}$, gdzie pomiędzy 2013 a 2014 rokiem jego wartość jest na identycznym poziomie. Wartości współczynników $X_{1}$ i $X_{3}$ mają stałą tendencję malejącą.

W dokonanych badaniach tylko dwa modele - autorstwa Jerzego Gajdki i Daniela Stosa oraz model „poznański” - informowały o możliwości upadłości podmiotu gospodarczego, począwszy od 2013 roku. Aczkolwiek tylko model „poznański” w sposób stanowczy alarmował o możliwym bankructwie. W trzech latach wskaźnik dyskryminacyjny znalazł się poniżej punktu granicznego - w modelu Elżbiety Mączyńskiej i Macieja Zawadzkiego. Warto jednak zauważyć, iż w 2013 roku wskaźnik znajdował się blisko punktu granicznego, więc można stwierdzić, iż sytuacja ekonomiczno-finansowa nie była w najlepszym stanie. Modele autorstwa Doroty Hadasik i Dariusza Wierzby tylko w ostatnich badanych latach wykazały zagrożenie upadłością. Natomiast zgodnie z modelem funkcji Artura Hołdy w żadnym $\mathrm{z}$ badanych okresów nie zanotowano zagrożenia bankructwem.

\section{Podsumowanie}

Wymienione modele nie są jednomyślne i jednakowo nie określają możliwości zagrożenia upadłością. Zastosowanie danych modeli może tylko nakreślić i zasugerować zagrożenie wiążące się z możliwymi problemami finansowymi i ekonomicznymi zaistniałymi w podmiocie gospodarczym. Dlatego te modele nie mogą w sposób jednoznaczny określić ryzyka i zagrożenia dla przedsiębiorstwa, lecz pozwalają tylko i wyłącznie zaprezentować, iż takowe niebezpieczeństwo zaistniało. Przedsiębiorstwa powinny brać pod uwagę wyniki płynące $\mathrm{z}$ tych wskaźników dyskryminacyjnych, lecz są zobowiązane także do tego, by mieć na uwadze, iż powody upadku nie muszą koniecznie pochodzić ze strony ekonomiczno-finansowej, gdyż mogą być spowodowane na przykład błędami organizacyjnymi.

Reasumując, zastosowane modele dyskryminacyjne dają obraz dotyczący zagrożeń oraz ryzyka bankructwem i upadłością, ale głównie od strony ekonomiczno-finansowej. Modele te zwracają mniejszą uwagę na strukturę organizacyjną, logistyczną czy sposoby zarządzania podmiotami gospodarczymi, co również może doprowadzić do upadku podmiotu gospodarczego.

Modele dyskryminacyjne są jednym z najpopularniejszych narzędzi pomiaru sytuacji ekonomiczno-finansowej przedsiębiorstwa i przyczyniają się do oceny ryzyka wystąpienia problemów finansowych prowadzących do bankructwa i upadłości podmiotu gospodarczego. W artykule zostały zastosowane wybrane polskie modele dyskryminacyjne na przykładzie spółki Alma Market SA. Zauważono, iż nie wszystkie modele dyskryminacyjne w jednakowych momentach wskazywały na ryzyko zaistnienia upadłości. Dlatego przedsiębiorstwa nie mogą opie- 
rać się wyłącznie na wynikach jednego modelu dyskryminacyjnego, lecz powinny brać pod uwagę wskaźniki większej ilości modeli dyskryminacyjnych.

\section{Literatura}

1. Antonowicz P. (2007), Metody oceny i prognozowania kondycji ekonomiczno-finansowej przedsiębiorstw, ODDK, Gdańsk.

2. Bombiak E. (2010), Modele dyskryminacyjne jako metoda oceny sytuacji finansowej przedsiębiorstwa, „Zeszyty Naukowe Akademii Podlaskiej w Siedlcach. Administracja i Zarządzanie", nr 86, s. 141-152.

3. Hadasik D. (1998), Upadłość przedsiębiorstw w Polsce i metody jej prognozowania, „Zeszyty Naukowe Akademii Ekonomicznej w Poznaniu" nr 153, seria 2: Prace Habilitacyjne, s. 198.

4. http://www.almamarket.pl/public/upload/data/07/52/75246_alma_market_sa_jednostkowesprawozdanie-finansowe-na-31-12-2013-rok.pdf (dostęp: 02.12.2017).

5. http://www.almamarket.pl/public/upload/data/07/52/75224_alma-market-sa_jednostkowesprawozdanie-finansowe-na-31-12-2014-rok.pdf (dostęp: 02.12.2017).

6. http://www.almamarket.pl/public/upload/data/07/52/75201_alma-market-sa_jednostkowesprawozdanie-finansowe-na-31-12-2015-rok.pdf (dostep: 02.12.2017).

7. http://www.almamarket.pl/public/upload/data/07/51/75147_alma-market-sa_jednostkowesprawozdanie-finansowe-na-31-12-2016-rok-korekta.pdf (dostęp: 02.12.2017).

8. Kasjaniuk M. (2006), Zastosowanie analizy dyskryminacyjnej do modelowania i prognozowania upadtości przedsiębiorstw, „Barometr Regionalny”, nr 2(6), s. 95-100.

9. Mączyńska E., Morawska S. (2015), Efektywność procedur upadłościowych. Bankructwa przedsiębiorstw. Katharsis i nowa szansa, Oficyna Wydawnicza SGH, Warszawa.

10. Pociecha J. (red.) (2014), Statystyczne metody prognozowania bankructwa w zmieniajacej się koniunkturze, Fundacja Uniwersytetu Ekonomicznego w Krakowie, Kraków.

11. Prusak B. (2005), Nowoczesne metody prognozowania zagrożenia finansowego przedsiębiorstw, Difin, Warszawa.

12. Rogowski W., Lipski M. (red.) (2014), Plynność finansowa przedsiębiorstw w Polsce. Uwarunkowania, zarządzanie płynnościa, ryzyko, Oficyna Wydawnicza SGH, Warszawa.

13. Rosiek J., Zyguła A. (2009), Upadłość przedsiębiorstw w Polsce - tendencje i perspektywy, „Zeszyty Naukowe Małopolskiej Wyższej Szkoły Ekonomicznej w Tarnowie”, nr 2(13), t. 2, s. 211-223.

14. Rupiewicz T. (2015), Ocena kondycji finansowej Przedsiębiorstwa Komunikacji Autobusowej Sp. z o.o., [w:] Grzywacz J. (red.), Finanse przedsiębiorstwa. Decyzje i efekty, Oficyna Wydawnicza SGH, Warszawa, s. 120-121.

15. Tłuczak A. (2013), Zastosowanie dyskryminacyjnych modeli przewidywania bankructwa do oceny ryzyka upadłości przedsiębiorstw, „Zeszyty Naukowe Wyższej Szkoły Bankowej we Wrocławiu", nr 2(34), s. 423-434.

16. Ustawa z dnia 15 maja 2015 r. - Prawo restrukturyzacyjne (Dz.U. 2015 poz. 978, z późn. zm.).

17. Ustawa z dnia 28 lutego 2003 r. - Prawo upadłościowe (Dz.U. 2003 nr 60 poz. 535, z późn. zm.). 


\title{
BANKRUPTCY OR MARKET STABILITY - ANALYSIS OF SELECTED POLISH DISCRIMINATORY MODELS. A CASE STUDY OF ALMA MARKET SA
}

\begin{abstract}
In times of unceasing globalization and striving for development, many business entities cannot cope with management, which leads them to bankruptcy. To minimize the risk of bankruptcy enterprises have the option of using discriminatory models. They are commonly known as early-warning models, which inform about the economic and financial situation of the enterprise. This article will analyze the case of Alma Market SA, which declared bankruptcy. The selected Polish discriminatory models will be used to define the coefficients determining the risk of a company going bankrupt in given periods.
\end{abstract}

Keywords: bankruptcy, discriminatory models, risk 